\title{
IMAGING SEAWATER INTRUSION IN COASTAL ZONE OF KAVALA (N. GREECE) WITH ELECTRICAL RESISTIVITY TOMOGRAPHY
}

\author{
Mertzanides Y. ${ }^{1}$, Economou N. ${ }^{2}$, Hamdan H. ${ }^{2}$, Vafidis A. ${ }^{2}$ \\ ${ }^{1}$ Prefecture of Kavala,65110, Kavala - Greece, mertzan@gmail.com \\ ${ }^{2}$ Lab.of Applied Geophysics, Tech.Univ.of Crete, 73100,Chania-Greece, vafidis@mred.tuc.gr
}

\begin{abstract}
The needs for water supply in the western coastal zone of Kavala (N. Greece) have been rapidly increased during the last decades because of the high tourist and agricultural development. This resulted to a number of wells that drilled along the coastline. During summer period, when human and irrigation consumptions are maximized, phenomena of groundwater salinization are observed. Although restrictions to new drillings have been taken, salinization in some aquatic systems of the area tends to become a major environmental and economical issue. The only available information till now was a timeseries of groundwater electrical conductivity measurements, in some of the wells of the area. This information is useful but not adequate for the study of the salt intrusion mechanism. Geophysical investigation was carried out and electrical resistivity tomography (ERT) was chosen as the most appropriate technique for the case. The geophysical survey was set in a site between the coastline and an existing borehole. The 2D ERT profiles gave a clear image of geoelectrical heterogeneities, associated with seawater intrusion in the coastal aquifers, contributing to future measures towards a rational management of ground water resources in the area.
\end{abstract}

Key words: seawater intrusion, coastal aquifers, electrical resistivity tomography, underground water conductivity, Prefecture of Kavala - N. Greece.

\section{Introduction}

Salinization of coastal aquifers is a major environmental problem for arid and semiarid regions of the planet. Its cause mechanism is related to the disturbance of the equilibrium between fresh and seawater in coastal water aquifers. Under normal conditions, the flow of underground freshwater toward the sea, maintains the boundary "fresh-saline water" zone near the cost and far below land surface. Overexploitation of ground water resources, due to overpumping wells or decrease of precipitation, displaces the boundary zone towards the land (Fig. 1a and 1b). This causes degradation to underground water quality and may result to ground subsidence with subsequent damages to buildings and infrastructure works, salinization of fertile soils and extinguish of aquatic ecosystems. Its quick and acute reaction to short and long-term climatic changes, may finally lead to desertification. Concerning the increasingly concentration of global population in coastal areas, it is obvious that this environmental problem has also ecological, social, cultural, economical and political aspects (Lambrakis and Kalergis, 2001; Kallergis, 2002). 

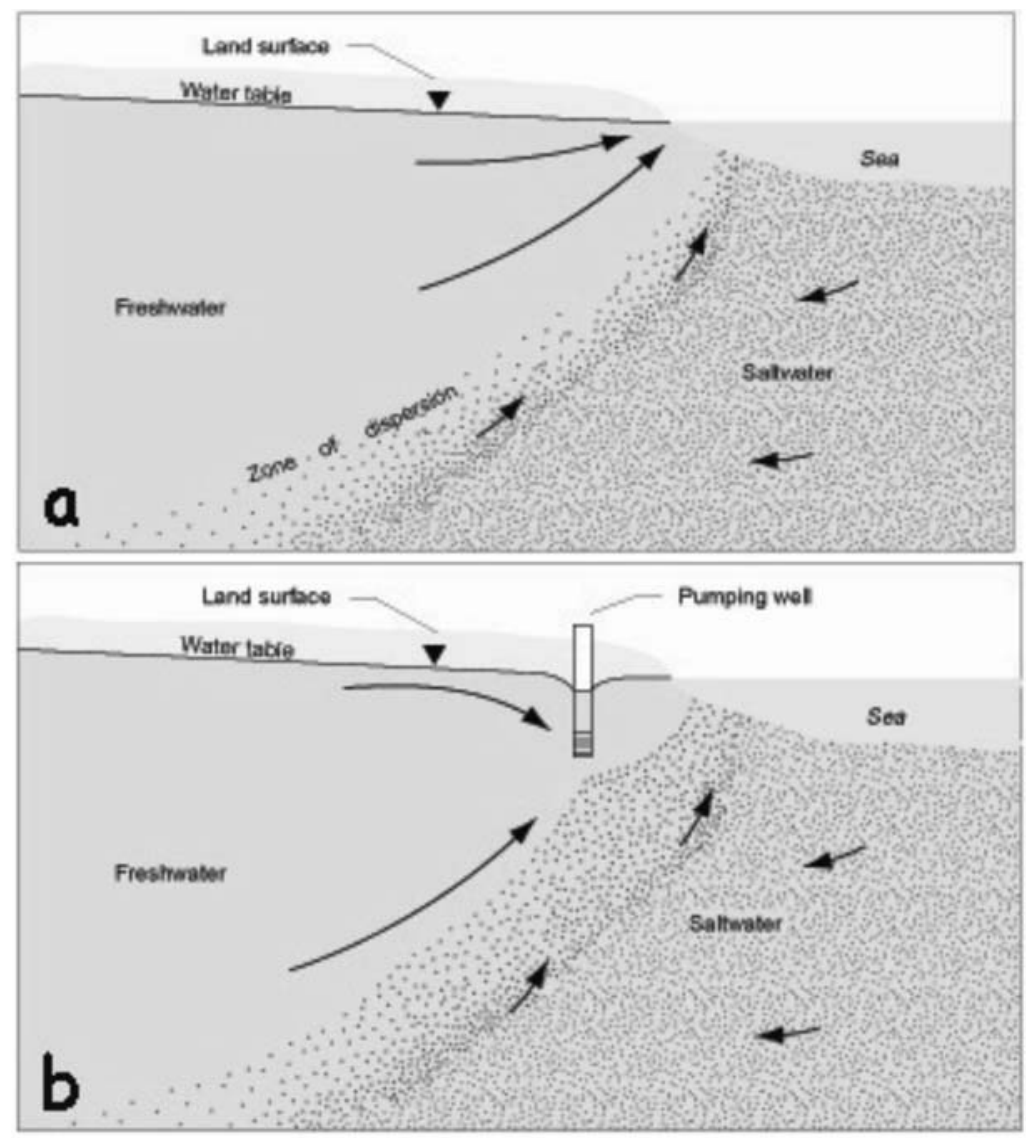

Fig. 1: Mechanism of salinization of coastal aquifers. a) The boundary fresh-saline water zone and b) Disturbance of this zone due to overpumping wells (From Barlow, P.M.; 2000; USGS Fact Sheet 085-00).

More or less common practices to reverse the seawater intrusion are (Bear et al., 1999; Ahlfeld and Mulligan, 2000; James et al., 2001; Ziegenbalg et al., 2002):

- Reduction of fresh water recovery.

- Relocation of coastal wells.

- Artificial surface recharge.

- Extraction of seawater before it reaches wells.

- Construction of impermeable subsurface barriers.

- Combination of the above.

A clear image of the extent and shape of saline water intrusion is the first step before planning any actions. At this step, geophysics appears to be an enlightening and reliable tool (Telford et al., 1990; Parasnis, 1997). Although geophysical survey is not new in ground water investigation, the advances in geophysical instrumentation and the development of sophisticated inverse algorithms, in the last two decades, made possible the fast acquisition and processing of large data sets (Kirsch, 2009). The result was quick information over large areas at a relatively in- 
expensive cost, compared to other methods e.g. borehole drilling and trenching. The use of geophysical measurements was established for mapping subsurface features, estimating properties and monitoring processes important to hydrologic studies, such as those associated with water resources and gave birth to "Hydrogeophysics" as a unique subdiscipline (Rubin and Hubbard, 2005; Hubbard and Rubbin, 2006; Vereecken et al., 2006; Miller, 2009).

In seawater intrusion imaging, resistivity methods are the most preferable, because electrical resistivity is highly sensitive to subsurface water saturation and pore water salinity (Archie, 1942; Barker, 1990; Mualem and Friedman, 1991; Ewing and Hunt, 2006). Among them, the Electrical Resistivity Tomography (ERT) is considered as one the most efficient techniques in imaging such properties and processes associated to subsurface geoelectrical structure (Daily et al., 1992; Park, 1998; Muller et al., 2003; Singha and Gorelick, 2005; Mohnke et al., 2006; Nguyen et al., 2009). In order to eliminate limitations of resolution decrease with increasing depth of investigation, ERT techniques based on variations of borehole, surface-to-borehole and cross-hole measurements, have been proposed (Asch and Morrison, 1989; Daily and Owen, 1991; Slater et al., 2000; Zhou and Greenhalgh, 2000; Friedel et al., 2004; Marescot et al., 2002; Tsourlos et al., 2004, 2005; Wilkinson et al., 2008). Along with spatial, ways for time resolution extent with time-lapse techniques, have been reported to literature (Tsourlos et al., 2003, 2005; Oldenborger et al., 2007).

This paper presents a study on imaging seawater intrusion in western coastal zone of Kavala (N. Greece). The ERT measurements were carried out by Laboratory of Applied Geophysics / Technical University of Crete and Georesources S.A., as part of the project: "Integrated system for water quality management and olive trees optimization, using Geographical Information Systems in Prefecture of Kavala", supervised by Directorate of Land Reclamation and Directorate of Planning and Programming/Prefecture of Kavala and carried out from November 2007 to November 2008, with consortium of contractors: DRAXIS S.A.-I.M.C. S.A. The project was $80 \%$ co-founded by the European Regional Development Fund, under the Framework of the Operational Program: Information Society (IS), Priority Axe: Action Line 2 - Citizens and Quality of Life, Measure 2.4 - Regional Geographical Information Systems and Innovative Actions.

\section{Selection of test site}

\subsection{General description}

The present study concerns the north Aegean coasts and particularly the western coasts of prefecture of Kavala. Prefecture of Kavala is located in the northeast of Greece and is the easternmost prefecture of geographic region of Macedonia. Nestos river from east, Strymonas river from west and Paggaeo and Lekani mountains, from north, are its physical borders. The area of the prefecture, including the island of Thassos, is $2.113 \mathrm{~km}^{2}$ and the population is 145.000 . Most of the major economical activities, tourism and agriculture are concentrated along the 200 kilometres of coastline, plus 115 kilometres more, on Thassos island. The western coasts, have been rapidly developed the last two decades mainly due to increasing touristic interest and secondly due to extended cultivation of vineyards and olive trees. The absence of significant surface water resources led to overexploitation of underground water resources and phenomena of salinization on coastal aquifers have been shown up. The test site is located 48 kilometres SW from Kavala, in Karyani coastal zone (Fig. 2).

Previous studies in nearby coastal zones of Macedonia and Thrace, based mostly on hydroge- 


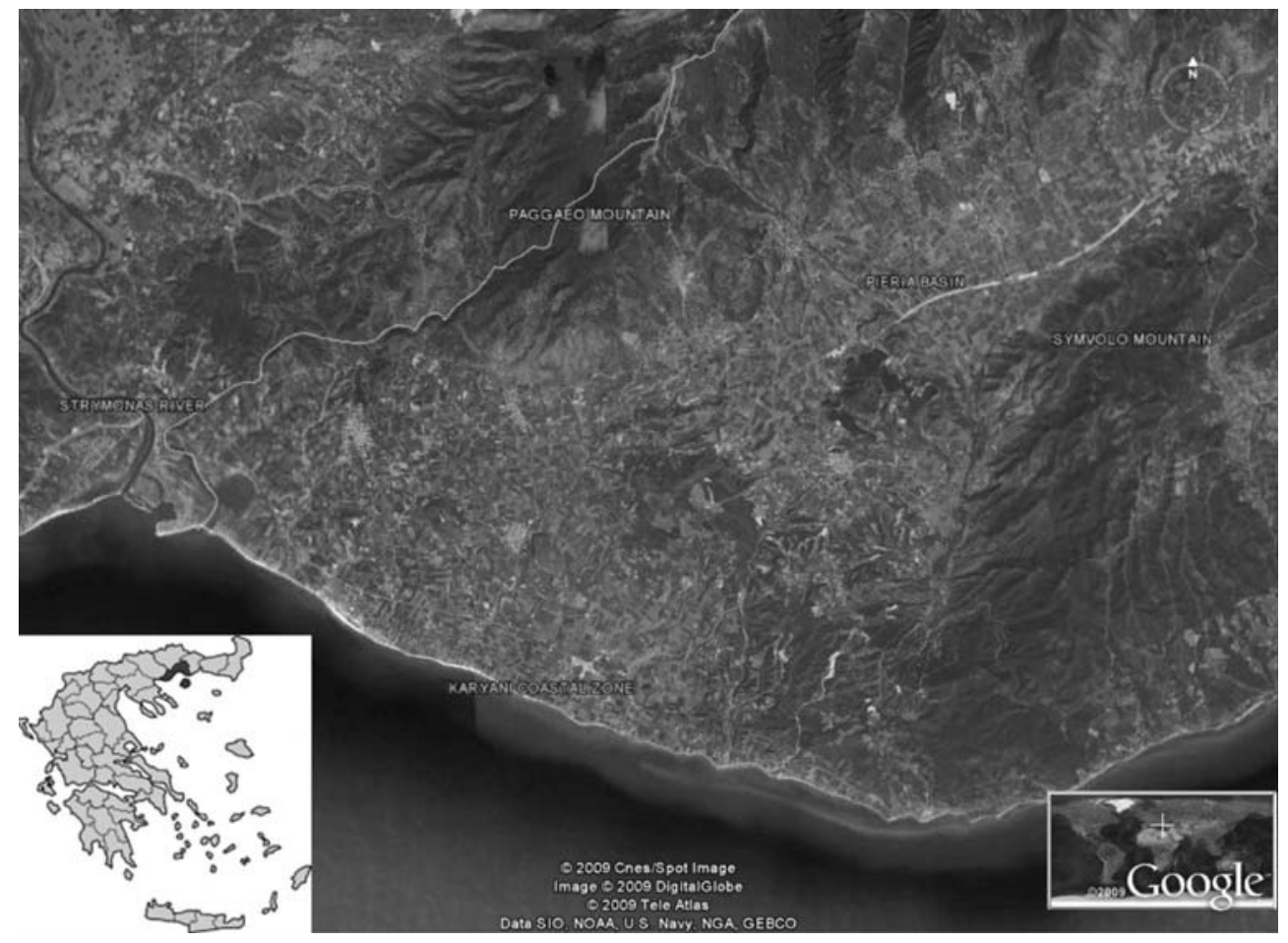

Fig. 2: Test site is located to western coasts of Kavala (N. Greece), to Karyani coastal zone.

ological and geochemical data, have pointed out the problem of seawater intrusion (Diamantis and Petalas, 1989; Petalas and Diamantis 1999; Pliakas et al., 2001; Ziegenbalg et al., 2002; Kallioras et al., 2006a and 20006b; Petalas et al., 2009).

\subsection{Geological-hydrological setting}

The test site is a strand plain, surrounded by a hilly landscape and is bounded by Symvolo mountain ridge to the east, Strymonas river to the west, Paggaeo mountain to the north and Aegean Sea to the south.

Geotectonically, the area at large of Karyani, is on the west border of Rhodope zone. It is composed by metamorphic (marbles. gneisses, schists), igneous (granodiorites) and sedimentary (mainly quaternary) rocks. The quaternary sediments are pleistocene and holocene deposits. The former, consists mainly of sand, pebbles, sandy clays and marls with frequent intercalations of calc-tufa lenses and loose conglomerates and has a thickness of $30 \mathrm{~m}$. The latter, which covers the area of interest, consists of fluviatile-torrential sediments, sand, pebbles, cobbles, fans and recent coastal deposits and has a thickness of 10-15 m.

The mean annual rainfall at Karyani as recorded by rain gauge station $1.2 \mathrm{~km} \mathrm{~W}$ from test site, is $408.5 \mathrm{~mm}$, while the maximum and minimum annual rainfall is $241.7 \mathrm{~mm}$ and $689.0 \mathrm{~mm}$, respectively (Petalas et al., 2004). The most dry period is May to September (29.7\% of annual rainfall) whereon the needs for water are highly increased. These facts show that Karyani has one of the most arid climates in the region of eastern Macedonia and Thrace and explain why 


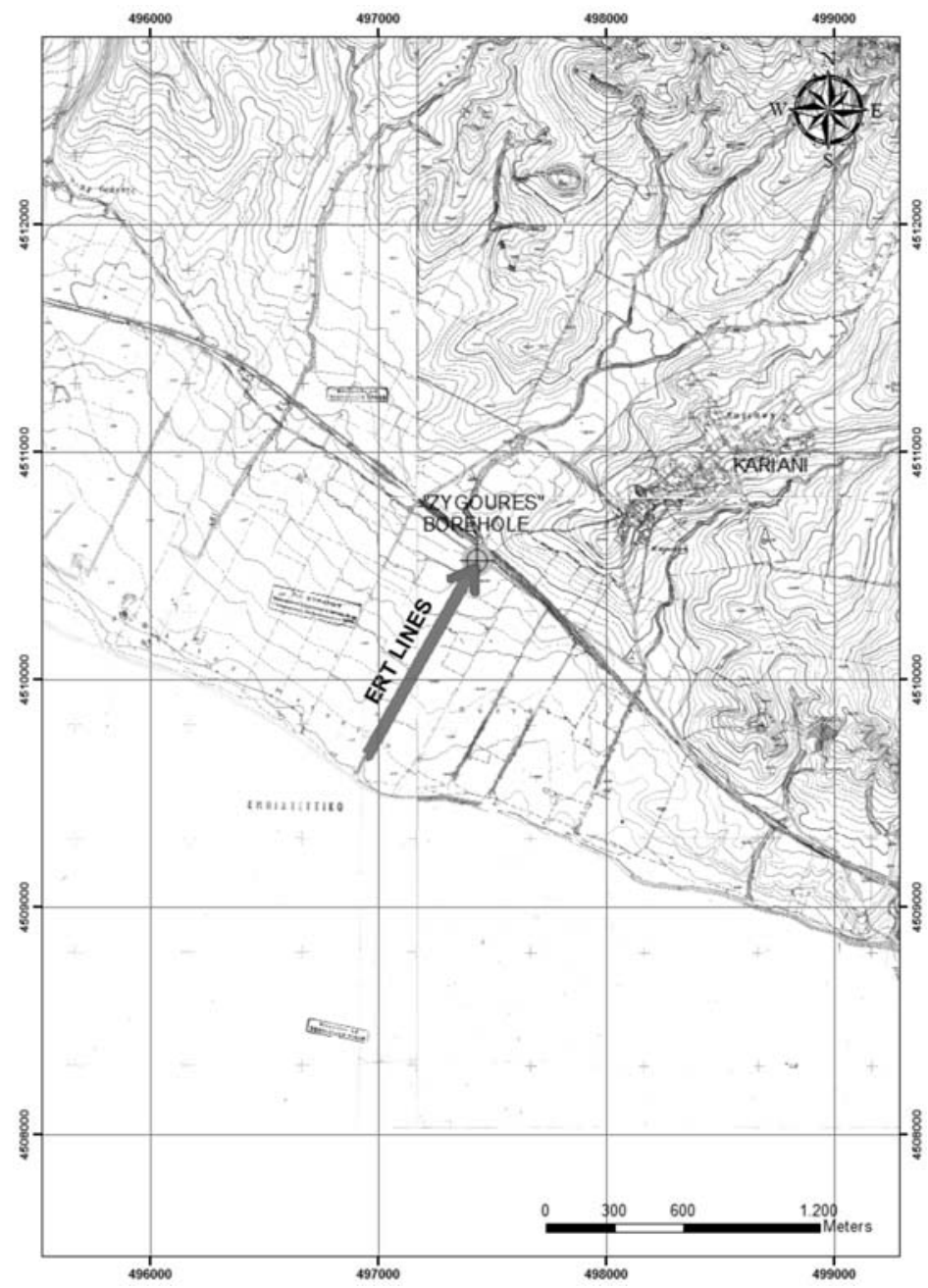

Fig. 3: The survey line started $80 \mathrm{~m}$ from sea shore and ended to "Zygoures" borehole.

during the period May to September there is an overexploitation of underground water resources. Groundwater recharge occurs by direct infiltration of atmospheric precipitations.

\section{Measurements and interpretation}

The objective of this study was to image the seawater intrusion in coastal aquifers. The ERT technique was considered to be the most appropriate mean for the achievement of this objective, since it provides information about the vertical and lateral changes of the electrical resistivity and is highly sensitive to saturated pore spaces. Moreover, the point information of high values of electrical conductivity in nearby wells, could be enhanced.

The survey line was in the SW-NE direction perpendicular to the seashore. It was selected by plan, to start $80 \mathrm{~m}$ from the coastline and end to an existed borehole, named "Zygoures" (Fig. 3). 

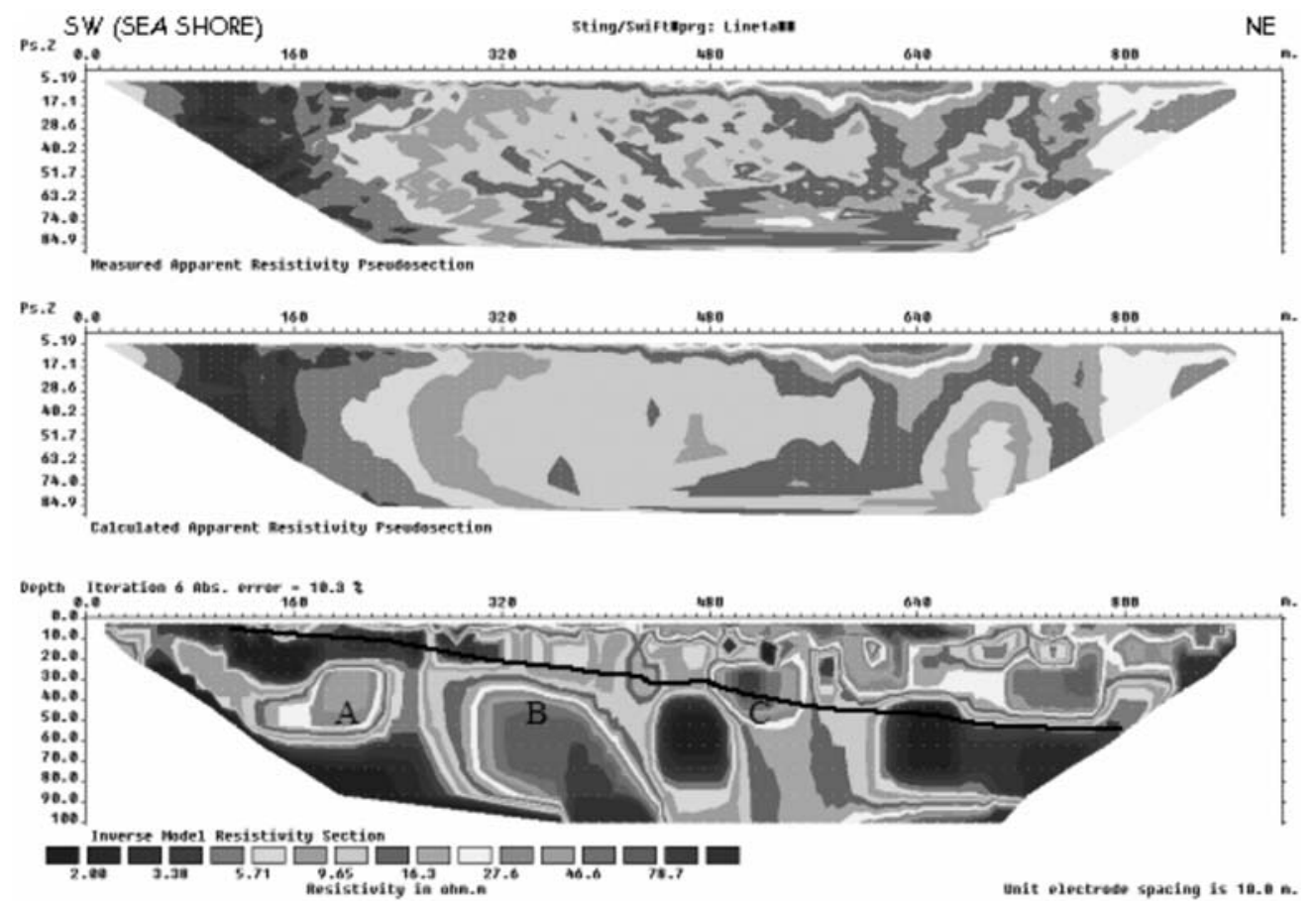

Fig. 4: Geoelectrical tomography line produced by robust inversion. Pseudosection of the measured (top) and calculated (middle) apparent resistivity. On the geoelectrical section (bottom) the black line indicates the subsaline water front. Three resistivity zones (A, B, C) are shown.

The borehole, has being pumped during the period May to September, to irrigate local fields. Measurements of electrical conductivity of pumping underground water, carried out by Directorate of Land Reclamation / Prefecture of Kavala, exhibited values that varied from 1200 to 4300 $\mu \mathrm{S} / \mathrm{cm}$, with pick values measured at the end of irrigation period.

The instrument used for ERT data acquisition was the AGI Sting R1 and measurements were carried out in the test site of Karyani, on August 2008. The Wenner-Schlumberger electrode array and the roll-along technique were applied. The electrode separation was $10 \mathrm{~m}$ and the survey line $930 \mathrm{~m}$. The roll-along technique employed four consecutive equal length spreads consisting of 49 electrodes. The recorded contact resistances at the electrodes were less than 1 $\mathrm{kOhm}$. Two geoelectric sections were obtained, by combining data from all the spreads and using the 2D inversion algorithms (the robust and the L2 norm) of RES2DINV software (Claerbout and Muir, 1973; Loke, 1998, 2002).

Fig. 4, displays the pseudosections of the measured and calculated apparent resistivity as well as the geoelectric section produced by robust inversion. The final inversion RMS error was $10.3 \%$, after rejecting $11 \%$ of the total sum of 1373 data collected. The geoelectrical section exhibits heterogeneity (the resistivity values range from 2 to $100 \mathrm{Ohm} \cdot \mathrm{m}$ ) and the depth of investigation approximately $100 \mathrm{~m}$. Very low resistivity zones present on this section could be attributed to formations of increased porosity and water salinity. The high values of electric conductivity (up to $4300 \mu \mathrm{S} / \mathrm{cm}$ ), measured on water samples of the nearby borehole, advocate 


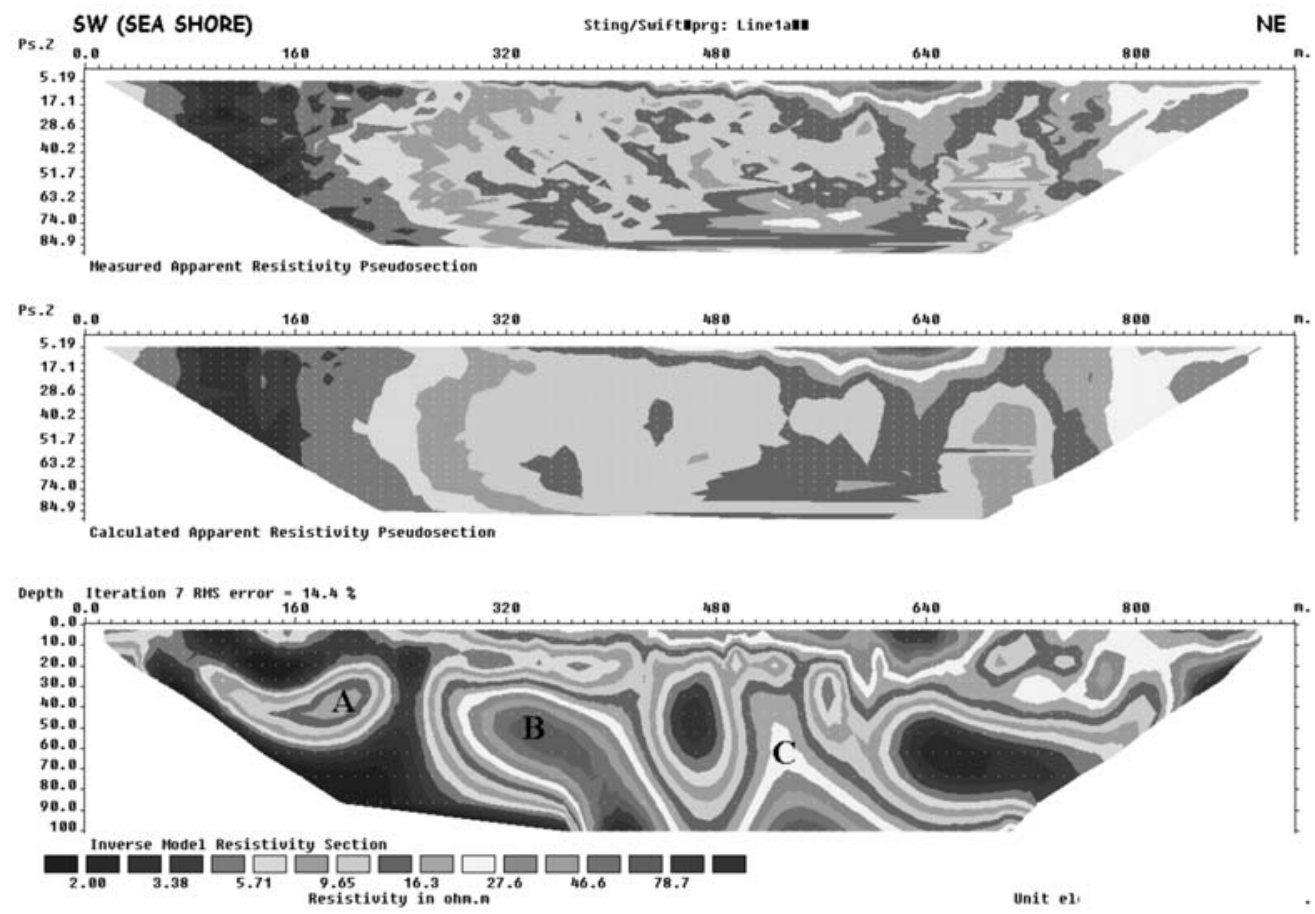

Fig. 5: Geoelectrical tomography line produced by L2 norm inversion. Pseudosection of the measured (top) and calculated (middle) apparent resistivity. The geoelectrical section (bottom) is smoother, compared to that on Fig. 4. The subsaline water front and the intermediate resistivity zones (A, B, C) are again clearly distinguished.

this interpretation. These zones are present at shallower depths (less than $10 \mathrm{~m}$ ) to the SW (close to the seashore). Their upper limit could define the subsaline water front. The high resistivity zones A, B and C (> $20 \mathrm{Ohm} \cdot \mathrm{m})$ are attributed to non-permeable formations such as marls, marly limestones and gypsum.

Fig. 5, displays the measured and calculated apparent resistivity pseudosections and the geoelectric section produced by the L2 norm inversion. The final inversion RMS error was $14.4 \%$, after rejecting $16 \%$ of the total sum of 1373 data collected. This geoelectrical section is smoother compared to that produced by robust inversion. The possible subsaline water front and the three resistivity zones $(\mathrm{A}, \mathrm{B}, \mathrm{C})$ are again clearly shown.

\section{Discussion and conclusions}

The seawater intrusion at western coasts of Kavala (N. Greece) was studied. The area was preferred because of its increasing touristic and agricultural development which followed by overexploitation of underground water resources. The test site was selected to start from sea shore and end to a borehole where the electric conductivity of pumping water had been measured, up to $4300 \mu \mathrm{S} / \mathrm{cm}$. Along this $1000 \mathrm{~m}$ line, measurements of apparent resistivity were carried out. Data were inverted and the 2D ERT profiles gave a clear image of underground inhomogeneities up to $100 \mathrm{~m}$ depth. 
The very low resistivities $(2-4 \mathrm{Ohm} \cdot \mathrm{m})$ in geoelectric section could be attributed to the sea water intrusion. The subsaline water front seems to displace fresh water up to $400 \mathrm{~m}$ to inland. There, it starts to incline into the underground aquifers, with $15^{\circ}$ angle, all along the ERT line. This could explain the high values of electrical conductivity measurements of ground water at the end of the survey line. ERT offered the first general image of ground water salinization in the area. It could guide to specific constraint measures for future wells (like distance from sea shore and maximum depth) and be an effective tool for rational management of ground water resources.

To better understand saltwater intrusion mechanism and subsurface heterogeneity in the area, deep, time-lapse ERT monitoring following the pumping schedule of the nearby borehole and chemical analysis of synchronous water samples could provide the complementary information.

\section{Acknowledgements}

We would like to thank Mr Constantinos Tsobanoglou, head of Directorate of Land Reclamation / Prefecture of Kavala, for his useful advice about the area of investigation. We also thank Mr C. Papaconstantinou, S. Zamanis, V. Gialamas and C. Samaras (from Georesources S.A.) for their work on field operations.

\section{References}

Ahlfeld, D.P., and A.E., Mulligan, 2000. Optimal management of flow in groundwater systems. Academic Press, London.

Archie, G. E., 1942. The electrical resistivity log as an aid in determining some reservoir characteristics. Transaction of American Institute of Mining, Metallurgical and Petroleum Engineers, 146, pp.54-62.

Asch, T.H., and H.F., Morrison, 1989. Mapping and monitoring electrical resistivity with surface and subsurface electrode arrays. Geophysics, 54, pp. 235-244.

Barker, R.D., 1990. Investigation of groundwater salinity by resistivity methods, Geotechnical and Environmental Geophysics, v. II, n. 5, Soc. Explor. Geophysicists, Inv. in Geophysics, (ed.) S. Ward, 201-212.

Bear, J., Cheng, A.H.-D., Sorek, S., Ouazar, D., and I., Herrera (eds.), 1999. Seawater intrusion in coastal aquifers-Concepts, Methods and Practices, Kluwer Academic Puplishers, 625 p.

Cheng, A.H.D.; Halhal, D., Naji, A., and D., Ouazar 2000. Pumping optimization in saltwater intruded coastal aquifers. Water Resources Research, 36, no.8, 2155-2166.

Claerbout, J.F., and F., Muir, 1973. Robust modeling with erratic data. Geophysics, 38, pp. 826-844.

Daily, W., and E. Owen, 1991. Cross-borehole resistivity tomography. Geophysics, 56, pp.1228-1235.

Daily, W., Ramirez, A., LaBrecque, D. and J., Nitao, 1992. Electrical resistivity tomography of vadose water movement. Water Resour. Res., 28, pp.1429-1442.

Diamantis, J., and C. Petalas, 1989. Sea water intrusion into coastal aquifers of Thrace and its impact on the environment. Toxicological and Environmental Chemistry, Vols. 20-21, pp. 291-305.

Directorate of Land Reclamation/Prefecture of Kavala, 2008. Record Room, Kavala.

Ewing, R. P., and A. G. Hunt, 2006. Dependence of the electrical conductivity on saturation in real porous media. Vadose Zone Journal, 5, pp.731-741.

Friedel S., Hansruedi Maurer H., Herfort M., and N., Van Meir, 2004. Application of single-hole geoelectrical tomography to characterize a coastal aquifer. SEG Technical Program Expanded Abstracts- 2004, pp.620-623. 
Hubbard, S.S., and Y. Rubin, 2006. Hydrogeological characterization using geophysical methods, in J. Delleur, ed., Handbook of groundwater engineering, CDCPress, section 14-1.

James, G.A., Hiebert, R., Warwood, B.K. and A., Cunningham, 2001. Subsurface biofilm barriers for controlling saltwater intrusion. Proceedings of $1^{\text {st }}$ International conference on saltwater intrusion and coastal aquifers-Monitoring, modeling and management. Essaouira, Morocco, April 23-25, 2001.

Kallergis, G., 2002. The salinization of aquifers from environmental point of view. Proceedings of $6^{\text {th }}$ Greek Hydrogeology Congress, Xanthi, Greece, 8-10 ${ }^{\text {th }}$ November 2002, pp.V-XII.

Kallioras, A., Pliakas, F., and I., Diamantis, 2006a. Conceptual model of a coastal aquifer system in northern Greece and assessment of salinevulnerability due to seawater intrusion conditions. Journal of Enveronmental Geology, (in press, DOI: 10.1007/s00254-006-0331-0).

Kallioras, A., Pliakas, F., Diamantis, I., and G., Kallergis, 2006b. Seawater intrusion and management of coastal aquifers in Greece: The case study of Rhodope weastern coastal aquifer. International Water Association, IWA, Proceedings of $10^{\text {th }}$ International Conference on Diffuse Pollution, Istanbul, Turkey, 18-22 September 2006.

Kirsch, R., 2009. Groundwater Geophysics: A tool for Hydrogeology, $2^{\text {nd }}$ ed. XX, Springer, 548 p.

Lambrakis, N., and G., Kallergis, 2001. Reaction of subsurface coastal aquifers to climate and land use changes in Greece. Modelling of groundwater refreshening patterns under natural recharge conditions. Journal of Hydrology, v.245, pp.19-31.

Loke, M. H., 1998. Rapid 2D resistivity IP inversion using the least-squares method. Program manula, Pengan, Malaysia.

Loke, M. H., 2002. 2D and 3D electrical imaging surveys, tutorial.

Marescot, L., Palma Lopes S., Lagabrielle R., and D., Chapellier, 2002. Designing surface-toborehole electrical resistivity tomography surveys using the Frechet derivative. Proceedings of the 8th Meeting of the Environmental and Engineering Geophysical Society - European Section, pp.289-292.

Miller, R., 2009. Editorial. The Leading Edge, S.E.G., Oct. 2009, v.28, no 10, p.1210.

Mohnke, O., Prokoph, K., and U., Yaramanci, 2006. Electrical resistivity tomography (ERT) as a tool for monitoring moisture dynamics in soil filled containers. Proceedings of 12th European Meeting of Environmental and Engineering Geophysics, B026.

Mualem, Y., and S.P., Friedman, 1991. Theoretical prediction of electrical conductivity in saturated and unsaturated soil. Water Resources Research, 27, pp.2771-2777.

Müller, M., Mohnke, O., Schmalholz, J., and U. Yaramanci, 2003. Moisture assessment with smallscale geophysics-The Interurban Project. Near Surface Geophysics, 1, pp.171-182.

National Statistical Service of Greece 2009. Latest statistical data: Population census 2001. Press Release NSSG, Athens.

Nguyen, F., Kemna, A., Antonsson, A., Engesgaard, P., Kuras, A., Ogilvy, R., Gisbert, J., Jorreto, S., and A., Pulido-Bosch, 2009. Characterization of seawater intrusions using 2D electrical Tomography. Near Surface Geophysics, Vol 7, pp.377-390. Special issue on Hydrogeophysics.

Oldenborger, G. A., Knoll, M., Routh, P., and D. LaBrecque, 2007. Timelapse ERT monitoring of an injection/withdrawal experiment in a shallow unconfined aquifer: Geophysics, 72, no. 4, pp.177-187.

Parasnis, D.S., 1997. Principles of Applied Geophysics. $5^{\text {th }}$ ed.: Chapman \& Hall.

Park, S., 1998. Fluid migration in the vadose zone from 3-D inversion of resistivity monitoring data. Geophysics, 63, no. 1, pp.41-51. 
Petalas, C., and I., Diamantis, 1999. Origin and distribution of saline groundwaters in the Miocene aquifer system in coastal Rhodope area, Thrace-NE Greece. Hydrogeology Journal, 7/3, pp.305-316.

Petalas, C., Pliakas, F., Diamantis, I., and A., Kallioras,2004. Study of the distribution of precipitation in district of eastern Macedonia and Thrace for the period 1964-1998. Bulletin of the Geological Society of Greece vol. XXXVI, Proceedings of the 10th International Congress, April 2004, Thessaloniki, Greece, pp. 1054-1064.

Petalas, C., Pisinaras, V., Gemitzi, A., Tsihrintzis, V.A., and K., Ouzounis, 2009. Current conditions of saltwater intrusion in the coastal Rhodope aquifer system, northeastern Greece. Desalination, 237 , pp. 22-41.

Pliakas, F., Diamantis, I., and C., Petalas, 2001. Saline water intrusion and ground water artificial recharge in east delta of Nestos river. Proceedings of $7^{\text {th }}$ International Conference on Environmental Science and Technology, University of Aegean, Dept. of Environmental Studies, and Global Nest, Ermoupolis, Syros, Greece, 3-6 ${ }^{\text {th }}$ September 2001, vol.2, pp.719-726.

Rubin, Y. and S.S. Hubbard, 2005. Hydrogeophysics, X, Springer, 523 p.

Singha, K., and S. M., Gorelick, 2005. Saline tracer visualized with three-dimensional electrical resistivity tomography: Field-scale spatial moment analysis. Water Resources Research, 41, W05023, doi: 10.1029/2004WR003460.

Slater, L., Binley, A.M., Daily, W., and R., Johnson, 2000. Cross-hole electrical imaging of a controlled saline tracer injection. Journal of Applied Geophysics, 44, pp.85-102.

Telford, W.M., Geldart, L.P., and R.E. Sheriff, 1990. Applied Geophysics, $2^{\text {nd }}$ ed.: Cambridge University Press.

Tsourlos, P., Ogilvy R.D., Meldrum P.I., and Williams G.M., 2003. Time-lapse monitoring in single boreholes using electrical resistivity tomography. Journal of Environmental and Engineering Geophysics, 8, pp.1-14.

Tsourlos, P., Ogilvy R.D., and C., Papazachos, 2004. Borehole-to-surface ERT inversion. Proceedings 10th European Meeting of Environmental and Engineering Geophysics, 6-9th September 2004, Utrecht, The Netherlands.

Tsourlos, P., Ogilvy R.D., and P., Meldrum, 2005. Time-lapse Monitoring using Borehole-toSurface Electrical Resistivity Tomography. Proceedings 11th European Meeting of Environmental and Engineering Geophysics, 6-9th September 2005, Palermo, Italy.

Vengosh, A., and E. Rosenthal, 1994. Saline groundwater in Israel: its bearing on the water crisis in the country. Journal of Hydrology, 156, pp. 389-430.

Vereecken, H., Binley, A., Cassiani, G., Revil, A., and K. Titov, 2006. Applied Hydrogeophysics, Proceedings of the NATO Advanced Research Workshop on Soils and Groundwater Contamination: Improved Risk Assessment, St. Petersburg, Russia, 25-29 July 2004. Series: NATO Science Series: IV: Earth and Environmental Sciences , Vol. 71, XII, 383 p.

Wilkinson, P B, Chambers, J E, Lelliott, M., Wealthall P., and R.D., Ogilvy 2008. Extreme sensitivity of crosshole electrical resistivity tomography measurements to geometric errors. Geophysical Journal International, Vol. 173, 49-62.

Zhou, B., and S.A., Greenhalgh, 2000. Cross-hole resistivity tomography using different electrode Configurations. Geophysical Prospecting, 48, pp.887-912.

Ziegenbalg, G., Dimitriadis, K., and E., Sarrikostis, 2002. CRYSTECHSALIN-A European project to manage and reduce saline water intrusion in coastal aquifers. Proceedings of $6^{\text {th }}$ Greek Hydrogeology Congress, Xanthi, Greece, 8-10 ${ }^{\text {th }}$ November 2002, pp.13-21. 